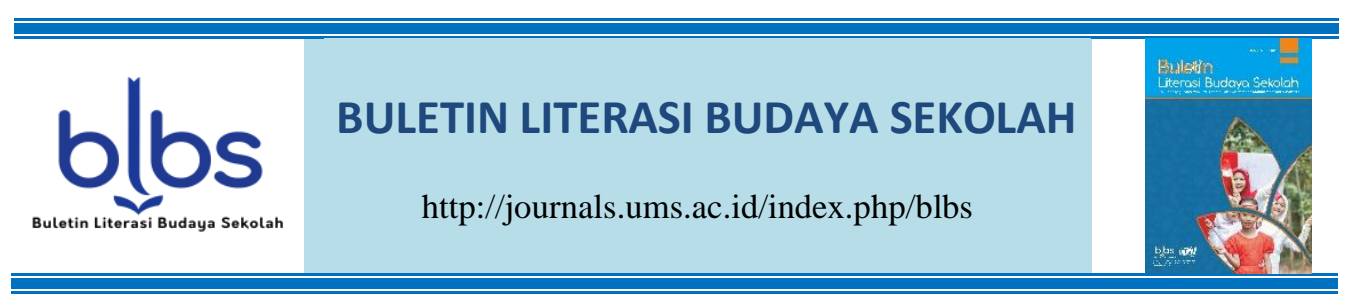

\title{
IMPLEMENTASI TEORI BELAJAR KONSTRUKTIVISTIK DALAM PEMBELAJARAN IPS UNTUK MENINGKATKAN PRESTASI BELAJAR SISWA DI SMP MUHAMMADIYAH 4 SAMBI
}

Danang Wahyu Hidayat ${ }^{1}$, Elvina Mukti Satiti ${ }^{2}, \&$ Wahyu Widiyatmoko ${ }^{3}$ 1,2,3 Universitas Muhammadiyah Surakarta

Jl. Ahmad Yani Tromol Pos 1, Surakarta, Indonesia

Email \& Phone: ww875@ums.ac.id +6285643718616

\begin{tabular}{|c|c|}
\hline Keywords: & Abstract \\
\hline $\begin{array}{l}\text { Constructivistic } \\
\text { learning } \\
\text { theory } \\
\text { learning } \\
\text { achievement } \\
\text { social studies } \\
\text { learning }\end{array}$ & $\begin{array}{l}\text { The low learning outcomes of students at SMP } \\
\text { Muhammadiyah } 4 \text { Sambi class VIII B in social studies are the } \\
\text { main and important problems faced by teachers. The purpose } \\
\text { of this study was to apply constructivist theory to the learning } \\
\text { outcomes of class VIII B SMP Muhammadiyah } 4 \text { Sambi in social } \\
\text { studies subjects. The method used in this research is Classroom } \\
\text { Action Research (CAR) which consists of two cycles and there } \\
\text { are four stages in each cycle, namely 1) planning, 2) } \\
\text { implementation, 3) observation, and 4) reflection. Data } \\
\text { collection was carried out through interview and observation } \\
\text { techniques. The results obtained from this study are that there } \\
\text { is an increase in learning achievement from cycle I and cycle II } \\
\text { in social studies subjects at SMP Muhammadiyah } 4 \text { Sambiclass } \\
\text { VIII B with the application of constructivist learning theory. }\end{array}$ \\
\hline
\end{tabular}

\section{PENDAHULUAN}

Pendidikan merupakan modal awal bagi keberlangsungan peradaban manusia di didunia. Pendidikan menjadi hal terpenting bagi bangsa Indonesia seperti yang sudah tercantum dalam UUD 1945 alenia IV yang berbunyi "salah satu tujuan nasional bangsa Indonesia adalah mencerdaskan kehidupan bangsa". Pendidikan nasional bertujuan untuk meningkatkan kemampuan siswa supaya menjadi manusia yang beriman dan bertaqwa serta memiliki moral yang menjadikan warga negara berdemokrasi dan bertanggung jawab. Bertujuan untuk menjadikan peradaban bangsa yang bermartabat dalam rangka mencerdaskan kehidupan bangsa (Undang-Undang Sistem Pendidikan Nasional (UUSPN) No.20 Tahun 2003 pasal 3)

Mata Pelajaran IImu Pengetahuan Sosial (IPS) Terpadu merupakan salah satu mata pelajaran yang diajarkan pada jenjang Sekolah Menengah Pertama (SMP). Beberapa penelitian menunjukkan bahwa hasil belajar IPS siswa masih 
dibawah standar ketuntasan minimal (Sholekhah \& Hadi, 2014), motivasi siswa dalam belajar IPS yang kurang (Sholekhah \& Hadi, 2014); (Sulfemi, 2018), cakupan materi IPS yang cukup luas (Utami \& Gafur, 2015). Penggunaan pendekatan yang menarik dalam pembelajaran IPS membuat siswa dapat dengan mudah memahami penjelasan yang diberikan sehingga sebagian siswa menjadikan pelajaran IPS sebagai pelajaran yang mudah untuk dipahami (Utami \& Gafur, 2015); (Wibowo \& Marzuki, 2015) tetapi masih saja ada siswa yang memiliki hasil belajar yang rendah karena siswa bersifat pasif saat proses belajar berlangsung. Faktor yang dapat mempengaruhi prestasi belajar adalah pendekatan belajar yang tepat, melalui pendekatan yang tepat dapat memberikan hasil yang lebih baik dan meningkatkan prestasi belajar siswa (Sumitro dkk, 2017); (Suprantini dkk, 2017); (Sarnoko dkk, 2016).

Konstruktivisme merupakan salah satu teori belajar yang banyak mempengaruhi pengetahuan dan berkembang dari aktivitas mengkontruksi bukan melalui transfer atau pemindahan (Permata dkk, 2018). Pendekatan konstruktivisme memiliki asumsi bahwa siswa dapat mengkonstruksi pengetahuannya sendiri melalui berbagai media yang ada. Posisi guru hanya sebagai mediator antara siswa dengan objek atau sumber belajarnya (Waseso, 2018). Teori belajar konstruktivisme memandang bahwa belajar lebih dari sekedar menerima dan memproses informasi yang sudah disampaikan oleh guru (Supardan, 2016). Kontruktivistik menganggap bahwa ilmu itu tidak didapat secara pasif, sebaliknya dibangun secara aktif oleh individu.gagasan yang dimiliki oleh guru tidak dengan mudah disalurkan pada siswa secara langsung melainkan siswa yang harus dapat berfikir secara kreatif dan inovatif dalam membentuk gagasan dalam individu.

Motivasi yang diberikan, kematangan materi, hubungan antara siswa dan guru, kemampuan siswa dalam menyampaikan pendapat, rasa aman, media pembelajaran merupakan hal yang mempengaruhi pembelajaran maka guru dalam pembuatan RPP harus dubuat sebaik mungkin. RPP yang berkualitas diharapkan dapat menciptakan suasana belajar yang menyenangkan di kelas. Tujuan dari peneilitian ini adalah untuk menerapkan teori belajar kontruktivistik guna meningkatkan hasil belajar dan prestasi yang baik.

\section{METODE}

Metode yang digunakan dalam penelitian ini menggunakan Penelitian Tindakan Kelas (PTK) dimana penelitian tindakan kelas merupakan cara yang tepat dalam penyempurnaan kegiatan belajar mengajar dalam lingkup pendidikan yang dilakukan oleh guru. Guru memberikan tindakan saat proses belajar mengajar yang bertumpu pada refleksi terhadap hasil tindakan tersebut. Tujuan utama dalam penelitian tindakan kelas agar mampu memperbaiki dan meningkatkan pembelajaran. Penelitian ini menggunakan dua siklus yang terdapat empat tahap disetiap siklus dalam rancangan penelitian ini yaitu 1) perencanaan, 2) pelaksanaan, 3) observasi, 4) refleksi. 


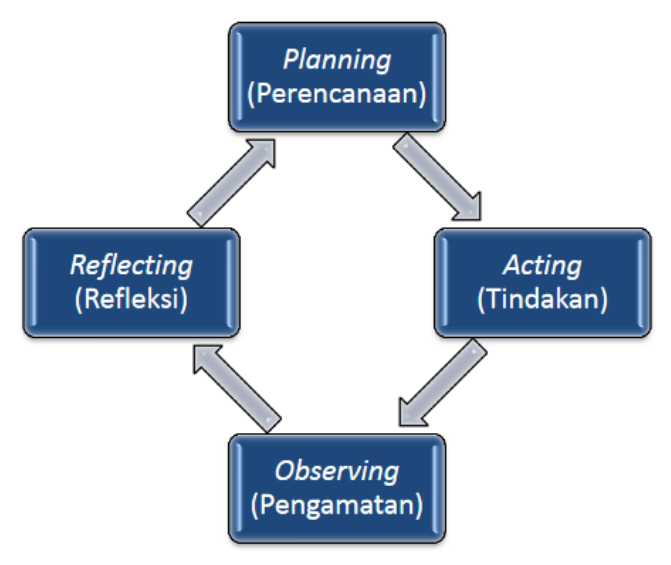

Gambar 1. Siklus penelitian tindakan kelas

Penelitian dilakukan pada bulan Januari sampai Februari tahun 2020 di SMP Muhammadiyah 4 Sambi. Subjek yang diambil dalam penelitian ini adalah kelas VIII B sebanyak 32 siswa Teknik pengambilan data dilakukan dengan menggunakan metode observasi dan wawancara. Tahapan penelitian meliputi 1) pengumpulan data, 2) menyajikan data, dan 3) menyimpulkan data.Kriteria kesuksesan dalam penelitian tindakan kelas adalah adanya perubahan yang ditunjukkan oleh siswa kelas VIII B SMP Muhammadiyah 4 Sambi yang meningkat selama kegiatan pembelajaran sesuai dengan kriteria ketuntasan (KKM) yang berlaku pada SMP Muhammadiyah 4 Sambi. Standar KKM di SMP Muhammadiyah 4 Sambi adalah individu minimal $70 \%$ dan pencapaian belajar klasikal minimal $80 \%$.

\section{HASIL DAN PEMBAHASAN}

SMP Muhammadiyah 4 Sambi merupakan sekolah menengah pertama yang berada dalam naungan pendidikan Muhammadiyah. SMP Muhammadiyah 4 Sambi memiliki jumlah siswa sebanyak 158 orang siswa. SMP Muhammadiyah 4 Sambi juga memiliki program pembelajaran yang berbeda dengan sekolah lain, yaitu pada saat sebelum melakukan pembelajaran jam pertama digunakan untuk pembiasaan sholat dhuha dan tadarus, pada jam terakhir digunakan untuk pembiasaan BTA, kemudian pada hari Sabtu dilakukan kegiatan tapak suci untuk kelas VII dan kelas VIII sedangkan untuk kelas IX melakukan tambahan pembelajaraan. Pada hari Jum'at dilaksanakan kegiatan Hizbul Wathan (HW) setelah sholat jum'at.

Guru membuat rancangan pelaksanaan pembelajaran pada materi "Peran Pelaku Ekonomi" di SMP Muhammadiyah 4 Sambi pada kelas VIII B. Rencana Pelaksanaan Pembelajaran merupakan bentuk penjabaran dari silabus kedalam unit satuan kegiatan suatu kegiatan belajar mengajar yang menerapkan beberapa indikator yang dilakukan dalam satu kali tatap muka. Dalam pembuatan RPP terkadang guru juga tidak terlalu mengacu hanya dengan satu model tetapi diberikan tambahan model pembelajaran seperti kontruktivistik. Dengan diadakan metode pembelajaran kontruktivistik ini melatih siswa untuk berpikir kritis. Guru menerapkan metode kontruktivistik hanya beberapa kali dalam satu semester dan langsung diambil penilaian melalui penugasan. 


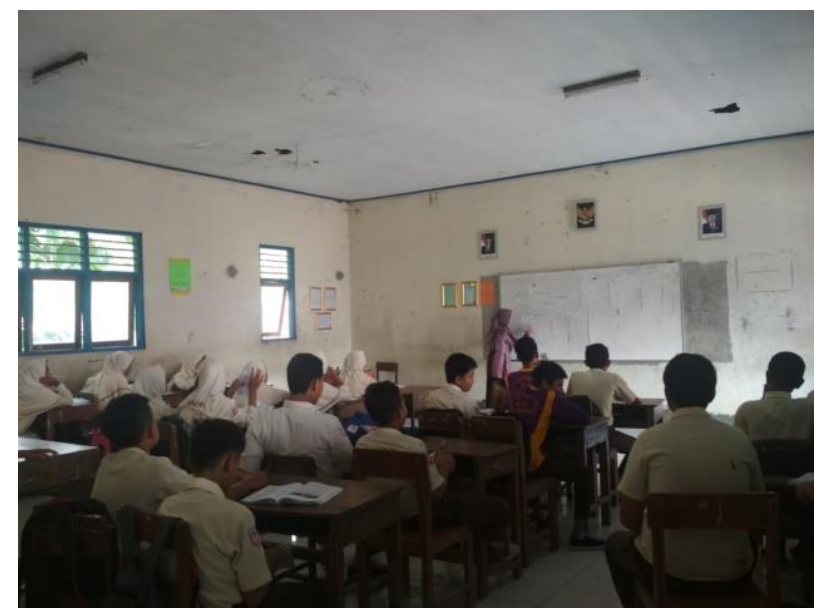

Gambar 2. Pembelajaran dengan model konstruktivistik

Data hasil evaluasi pembelajaran dalam metode kontruktivistik evaluasi yang digunakan yaitu nilai dari penugasan seperti memberikan pendapat tentang suatu gambar atau yang lainnya, dalam penugasan siswa harus mampu menyimpulkan gagasan untuk membantu siswa mampu berfikir kritis, dalam kegiatan belajar mengajar guru harus menampilkan suasana belajar dengan cara berdidkusi. Suasana penerapan pembelajaran konstruktivistik di kelas VIII B disajikan pada Gambar 2. Pembelajaran yang berbasis kolaborasi mengakibatkan siswa mampu menuangkan kreatifitas yang dimiliki setiap individu, mengembangkan kognitif siswa, serta dapat melatih pengalaman, keberanian dan berpendapat bagi siswa.

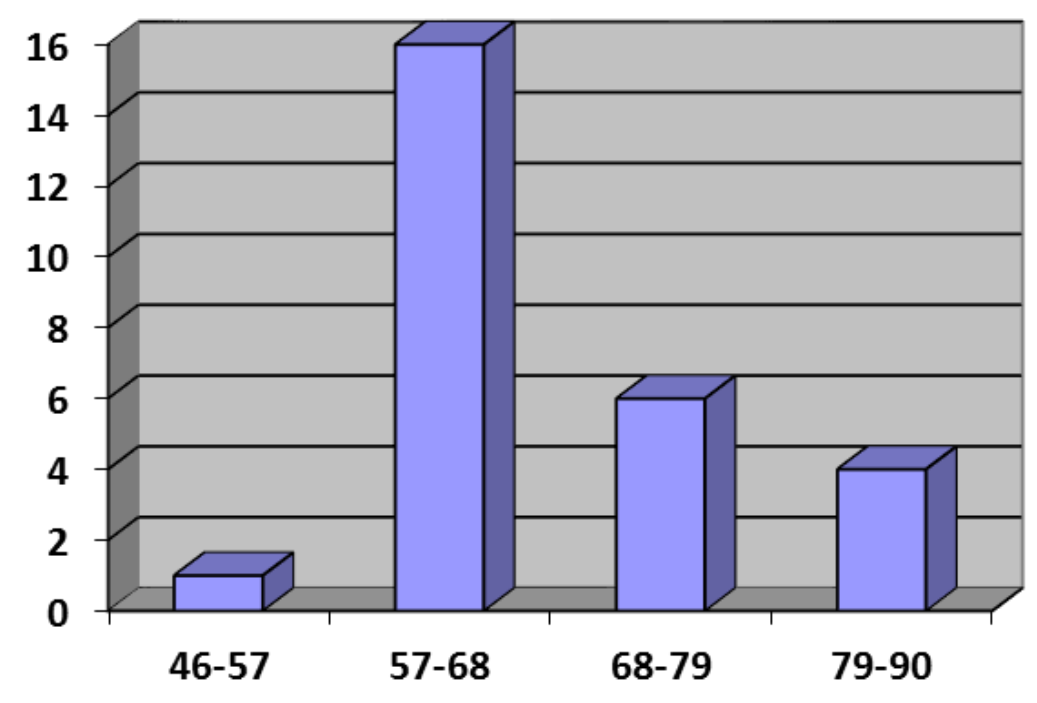

Gambar 3. Nilai penugasan pada siklus I 


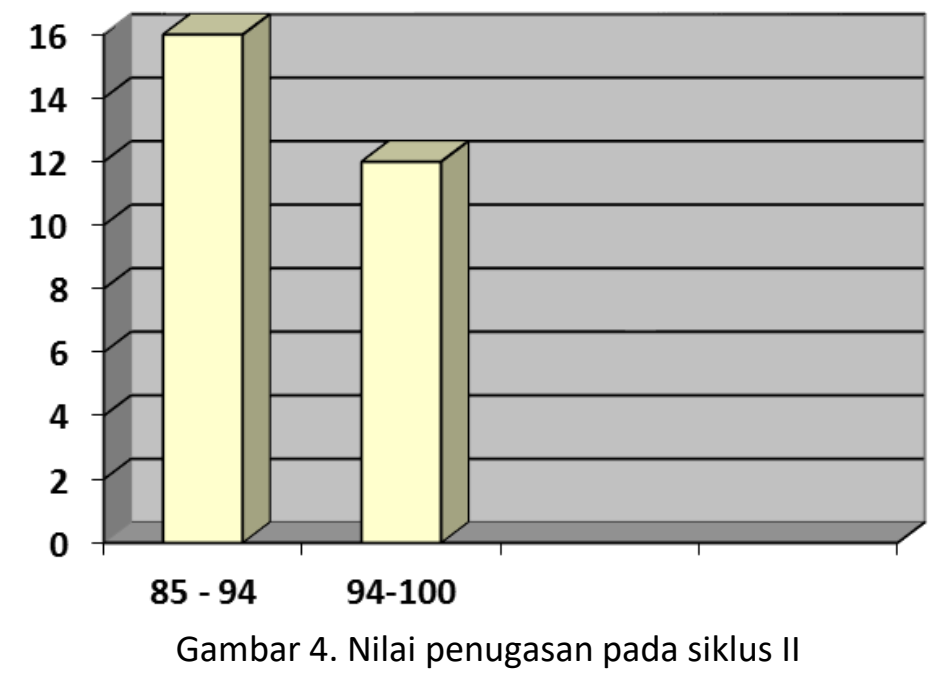

Adapun hasil analisis penugasan pada siklus I, dari 30 orang siswa hanya terdapat 10 siswa lolos KKM pada penugasan yang diberikan oleh guru. Pencapaian belajar klasikal $33,33 \%$ dan nilai rata-rata $66,86 \%$, sedangkan hasil analisis penugasan pada tahap kedua, 28 orang siswa telah mencapai ketuntasan klasikal yang mencapai $100 \%$, didapatkan 28 orang siswa yang tuntas atau ketuntasan klasikal mencapai $100 \%$ dimana dari 28 orang siswa semua tuntas pada tahap kedua didapatkan nilai rata-rata $91,42 \%$. Grafik nilai penugasan pada siklus I dan siklus II disajikan pada Gambar 3 dan Gambar 4.

Penelitian melalui metode observasi tentang aktifitas siswa mendapatkan hasil yang meningkat, siswa mengalami peningkatan prestasi dalam pelaksanaan aktifitas pada tahap pertama sebesar $66,86 \%$ termasuk dalam kategori cukup sedangkan tahap kedua sebesar $91,42 \%$ termasuk dalam tingkatan yang yang berpredikat baik sekali, sehingga mengalami peningkatan dari tahap pertama ke tahap kedua mencapai $25 \%$. Pada siklus I siswa masih mengalami kesulitan dalam menerima pembelajaran IPS, siswa juga tidak mau untuk mengemukakan pendapat. Siswa hanya mengandalkan materi yang disampaikan guru saat proses belajar mengajar, akhirnya pada tahap ini siswa lebih bersifat pasif maka guru yang harus bersifat aktif dalam memberikan materi. Pada siklus II siswa sudah mulai terbiasa dengan teori yang digunakan oleh guru sudah mulai berani untuk mengungkapkan pendapat, menyanggah pertanyaan dari teman, saling bertukar pikiran, mulai aktif bertanya.

Hasil penelitian yang dilakukan di SMP Muhammadiyah 4 Sambi yang diambil dari hasil evaluasi penugasan menunjukkan bahwa penerapan teori belajar kontruktivistik dapat meningkatan hasil belajar siswa secara bertahap dengan hasil yang memuaskan. Sebanyak 33,33\% siswa telah mencapai KKM dalam pembelajaran pada siklus I. Pada siklus II, 100\% siswa telah mencapai KKM. Hasil belajar siswa telah mengalami peningkatan dari siklus I ke siklus II mencapai $25 \%$.

Berdasarkan hasil penelitian tersebut, penerapan teori kontruktivistik dalam proses pembelajaran siswa menjadikan siswa mampu berfikir kritis sehingga siswa dapat mengemukakan pendapat dengan benar. Siswa mendapat pengetahuan yang lebih luas dan lebih bermakna selama proses pembelajaran. 
Danang Wahyu Hidayat ${ }^{1}$, Elvina Mukti Satiti ${ }^{2}$, \& Wahyu Widiyatmoko ${ }^{3}$, Implementasi Teori Belajar Konstruktivistik

\section{SIMPULAN}

Penerapan teori belajar kontruktivistik yang dilakukan guru SMP Muhammadiyah 4 Sambi, kelas VIII B memberikan dampak yang baik bagi prestasi belajar siswa dari siklus I ke siklus II. Hasil belajar siswa mengalami peningkatan yang cukup baik, oleh dari itu teori belajar kontruktivistik dapat membuat siswa lebih berpikir kritis dalam proses pembelajaran dan lebih kreatif dalam menyampaikan pendapat serta dalam menuangkan ide.

\section{DAFTAR PUSTAKA}

Permata, L. D., Rahmawati, D., \& Fitriana, L. (2018). Pembelajaran matematika SMP dalam perspektif landasan filsafat konstruktivisme. Jurnal Elektronik Pembelajaran Matematika, 5(1), 32-43.

Sarnoko, S., Ruminiati, R., \& Setyosari, P. (2016). Penerapan Pendekatan Savi Berbantuan Video Pembelajaran untuk Meningkatkan Aktivitas dan Hasil Belajar IPS Siswa Kelas IV Sdn I Sanan Girimarto Wonogiri. Jurnal Pendidikan - Teori, Penelitian, Dan Pengembangan, 1(7), 1235-1241.

Sholekhah, I. M., \& Hadi, S. (2014). Pengaruh Fasilitas Belajar dan Lingkungan Keluarga Terhadap Hasil Belajar IPS Terpadu Melalui Motivasi Belajar SMP Negeri 1 Ambarawa (Studi Kelas VII Tahun Ajaran 2013/2014). Economic Education Analysis Journal, 3(2), 372-378.

Sulfemi, W. B. (2018). Hubungan Motivasi Belajar Dengan Hasil Belajar IPS di SMP Kabupaten Bogor. EDUTECNO : Jurnal Pendidikan Dan Administrasi Pendidikan, 18(1), 1-12.

Sumitro, A. H., Setyosari, P., \& Sumarmi. (2017). Penerapan Model Problem Based Learning meningkatkan Motivasi dan Hasil Belajar IPS. Jurnal Pendidikan:Teori, Penelitian, Dan Pengembangan, 2(9), 1188-1195. Retrieved from http://journal.um.ac.id/index.php/jptpp/article/view/9936/4696

Supardan, D. (2016). Teori dan Praktik Pendekatan Konstruktivisme dalam Pembelajaran. Edunomic, 4(1), 1-12.

Suprantini, E., Rohaetin, S., \& Oktobery, R. (2017). Upaya Peningkatan Prestasi Belajar IPS Terpadu Melalui Pendekatan Komunitas Belajar di Kelas VIII SMPN-3 Parenggean Tahun Pelajaran 2016/2017, 8(2), 21-28.

Utami, P. S., \& Gafur, A. (2015). Pengaruh Metode Pembelajaran Dan Gaya Belajar Siswa Terhadap Hasil Belajar IPS Di SMP Negeri Di Kota Yogyakarta. Harmoni Sosial: Jurnal Pendidikan IPS, 2(1), 97-103. https://doi.org/10.21831/hsjpi.v2i1.4622

Waseso, H. P. (2018). Kurikulum 2013 Dalam Prespektif Teori Pembelajaran Konstruktivisme. Ta'lim: Jurnal Studi Pendidikan Islam, 1(1), 59-72.

Wibowo, K. P., \& Marzuki, M. (2015). Penerapan Model Make a Match Berbantuan Media Untuk Meningkatan Motivasi dan Hasil Belajar IPS. Harmoni Sosial: Jurnal Pendidikan IPS, 2(2), 158-169. https://doi.org/10.21831/hsjpi.v2i2.7667 